\title{
Milk and Cheese Fatty Acid Composition in Sheep Fed Mediterranean Forages with Reference to Conjugated Linoleic Acid cis-9,trans-11
}

\author{
M. Addis, A. Cabiddu, G. Pinna, M. Decandia, G. Piredda, A. Pirisi, and G. Molle \\ Istituto Zootecnico e Caseario per la Sardegna, Loc. Bonassai, 07040, Italy
}

\begin{abstract}
Two experiments were undertaken to evaluate the effect on milk and cheese fatty acid composition of feeding different fresh forages to dairy sheep both in winter (experiment 1, growing stage of the forages, early lactating ewes) and in spring (experiment 2 , reproduction stage of the forages, midlactating ewes). Four forage species were compared: annual ryegrass (RY, Lolium rigidum Gaudin), sulla (SU, Hedysarum coronarium L.), burr medic (BM, Medicago polymorpha L.), and a daisy forb ( $\mathrm{CH}$, Chrysanthemum coronarium L.). The forages were cut twice daily and offered ad libitum to 4 replicate groups of Sarda dairy sheep (groups RY, SU, $\mathrm{BM}$, and $\mathrm{CH}$ ). The $\mathrm{CH}$ forage was particularly rich in linoleic acid in both periods, whereas BM and SU forages were rich in linolenic acid in winter and spring, respectively. Milk fatty acid composition was affected by the forage in both experiments. Milk conjugated linoleic acid and vaccenic acid contents were higher in $\mathrm{CH}$ and $\mathrm{BM}$ groups (winter) and $\mathrm{CH}$ group (spring) than in the other groups. No differences were observed when comparing fatty acid profile between milk, 1-d-old cheeses, and 60-d-old cheeses within experimental groups, suggesting that the fatty acid recovery rates during cheese making and ripening were not affected by the feeding regimens. After stepwise discriminant analyses of the pooled data, the milks and cheeses sourced in the different feeding regimens differed among them. Based on these results, we conclude that it is possible to manipulate the fatty acid profile of sheep dairy produce to maximize the content of beneficial fatty acids by the use of appropriate fresh forage-based regimens.
\end{abstract}

(Key words: sheep milk, cheese, fatty acid, conjugated linoleic acid)

Abbreviation key: $\mathbf{B M}=$ burr medic, $\mathbf{C H}=$ Chrysan themum coronarium, CLA = conjugated linoleic acid, LCFA = long-chain fatty acids, MCFA = medium-chain

Received March 7, 2005.

Accepted June 6, 2005.

Corresponding author: M. Addis; e-mail: maraddis@tiscali.it. fatty acids, $\mathbf{R Y}=$ annual ryegrass, $\mathbf{S C F A}=$ short-chain fatty acids, $\mathbf{S U}=$ sulla, $\mathbf{V A}=$ vaccenic acid .

\section{INTRODUCTION}

It is widely recognized that diet plays a major role in modulating the fatty acid composition of ruminant milk as recently reviewed with specific focus on cattle (Jensen, 2002), goats (Chilliard et al., 2003), and sheep (Bocquier and Caja, 2001). It has also been recognized for some time that the intake of fresh forages either cut and offered in trough or grazed has an influence on milk fat as well as on milk fatty acid composition compared with diets based on conserved forage and concentrates (Kuzdal-Savoie and Kuzdal, 1961). However, it is unclear whether the "herbage effect" depends upon the forage species. As far as cow milk is concerned, an early report by Decaen and Ghadaki (1970) showed no differences in milk fatty acid composition between cows fed lucerne, perennial ryegrass, or cocksfoot, even if the range of variability in fatty acid composition was much higher in cows fed ryegrass than in cows fed other forage species. More recently, Delegarde and Peyraud (2002) detected slight but significant differences in the fatty acid profiles, comparing tall fescue to diploid and tetraploid cultivars of perennial ryegrass. Collomb et al. (2002) observed a significant influence on milk fatty acid composition of high-altitude compared with medium-altitude mountain grassland grazed by dairy cows. This observation was related to the intake of higher quantities of nonleguminous herbaceous dicotyledons in the high-altitude pastures. With reference to Sarda dairy sheep, Piredda et al. (2002) showed a significant effect of the forage species on milk fatty acid composition comparing feeding regimens based on monocultures of sulla (Hedysarum coronarium) and annual ryegrass (Lolium rigidum Gaudin). Recent studies have also highlighted that fatty acids composition of forage species is modulated by factors such as forage cultivar (Elgersma et al., 2003), stage of maturity (Dewhurst et al., 2001), intensity of defoliation (Dewhurst et al., 2001), time interval between cutting and forage consumption (Offer, 2002), and forage conservation techniques (French et al., 2000; Chilliard et al., 2001). Therefore, the wide range of fatty acid composition of 
the fresh forages, its variability during the growing cycle, and the changes subsequent to cutting or grazing could affect the availability of these fatty acids to rumen biohydrogenation and finally their postruminal fate (uptake by mammary gland, saturation-desaturation processes, and transfer to milk) (Bauchart et al., 1984).

Several studies on dairy cattle have recently pointed out the potential of grazing for enhancing the proportion in milk and dairy products of conjugated linoleic acid isomers (CLA), a collective term that encompasses an array of geometric and positional isomers of conjugated C18:2 (Dhiman et al., 1999; Lock and Garnsworthy, 2003). In the last decades, the potential anticarcinogenic and antiatherogenic effects of an isomer of CLA, C18:2 cis-9,trans-11 (rumenic acid), have been highlighted (Ip et al., 2002; Parodi, 2003). These studies emphasize the importance of increasing the content of rumenic acid in dairy products.

Results from the literature are largely focused on dairy cows, and information on small ruminant species such as sheep is still scarce (Perea et al., 2000). Banni et al. (1996) noted that sheep milk and "Pecorino" sheep cheese from the Sarda dairy breed are particularly rich in CLA compared with an array of products from dairy cattle. One possible reason could be that sheep are usually fed on pasture whereas dairy cattle generally receive diets based on conserved forages and concentrates. Mediterranean pastures are based upon selfseeding grasses (e.g., annual ryegrass, Lolium rigidum Gaudin) and legumes (e.g., burr medic, Medicago polymorpha L.) or short-lived legumes, like the sulla. These forages are an important component of Mediterranean grazing systems for dairy sheep, showing specific beneficial features in terms of persistence, forage production, forage quality, and animal response (Molle et al., 2002; Rochon et al., 2004). Other species are interesting for dairy sheep grazing systems, namely nonconventional forages palatable to grazing sheep, such the Asteracea Chrysanthemum coronarium L. (Sulas et al., 1999). This species is highly productive and can complement grass-based systems as well as other nonconventional daisy forages such as chicory (Chicorium intybus; Hume et al., 1995) or spineless safflower (Carthamus tinctorius; Landau et al., 2004). In particular, it has been found that sheep grazing Chrysanthemum coronarium during springtime ingest the daisy flowers, putatively raising their intake of CLA precursors, which are concentrated in the flowers (Sulas et al., 1999). This can be relevant to Mediterranean dairy sheep systems in which a general decrease of milk CLA is observed during spring, when pasture turns from the vegetative to reproductive phase (Cabiddu et al., 2003).

The present study was aimed at evaluating the effect of feeding fresh forages of different Mediterranean spe- cies on the fatty acid composition of sheep milk and cheese, with special emphasis on the content of CLA and its precursors.

\section{MATERIALS AND METHODS}

\section{Site}

The experiment was carried out at the Bonassai experimental farm of the Istituto Zootecnico e Caseario per la Sardegna (NW Sardinia, latitude: $41^{\circ} \mathrm{N}$, average annual rainfall $=547 \mathrm{~mm}$ ).

\section{Forages}

Four forage species were compared: annual ryegrass (RY, Lolium rigidum Gaudin), sulla (SU, Hedysarum coronarium L.), burr medic (BM, Medicago polymorpha L.), and a daisy forb (CH, Chrysanthemum coronarium L.). Four experimental plots (each of $3750 \mathrm{~m}^{2}$ ) were sown in October ( $\mathrm{CH}$ and $\mathrm{BM}$ ) or November (RY and SU). The seeding rate was $40 \mathrm{~kg} / \mathrm{ha}$ for ryegrass and sulla, $35 \mathrm{~kg} / \mathrm{ha}$ for burr medic, and $100 \mathrm{~kg} / \mathrm{ha}$ for Chrysanthemum coronarium.

The plots were fertilized at seeding with $92 \mathrm{~kg}$ of $\mathrm{P}_{2} \mathrm{O}_{5} / \mathrm{ha}$ (all plots) and $36(\mathrm{RY})$ or $60 \mathrm{~kg}$ of N/ha $(\mathrm{CH})$. Fertilizer overtopping was carried out only on the ryegrass plot on 2 occasions in February and March (52 $\mathrm{kg}$ of $\mathrm{N} / \mathrm{ha}$ as total).

Two experiments were conducted in two 3 -wk periods: experiment 1 was carried out in winter during the vegetative phase of the forages (February-March) and experiment 2 in spring during the reproductive phase of the forages (April-May). The choice was based on the visual inspection of the growing phase of the herbage (Andrieu et al., 1988).

The forages were mechanically mown twice daily, cutting the sward at a stubble height of 4 to $6 \mathrm{~cm}$ measured by a weighed square grass-meter (Holmes, 1974). The sward height at cutting was kept in a range 300 to $400 \mathrm{~mm}$ during the experimental periods.

\section{Chemical Composition of Forages and Ingested Diets}

Forage and orts were sampled weekly and kept frozen at $-20^{\circ} \mathrm{C}$ until processed for further analysis. Forage samples were freeze-dried and then ground through a 1-mm screen before analyses. Contents of CP and ether extract were determined (AOAC, 1980). Analysis of $\mathrm{NDF}$ and $\mathrm{ADF}$ were determined using an Ankom fiber analyzer using the filter bag technique (Ankom Technology Corp., Fairport, NY). Lipid extraction was carried out according to a modified Folch method (Christie, 
Table 1. Chemical composition of the offered forages ${ }^{1}$ and ingested diets.

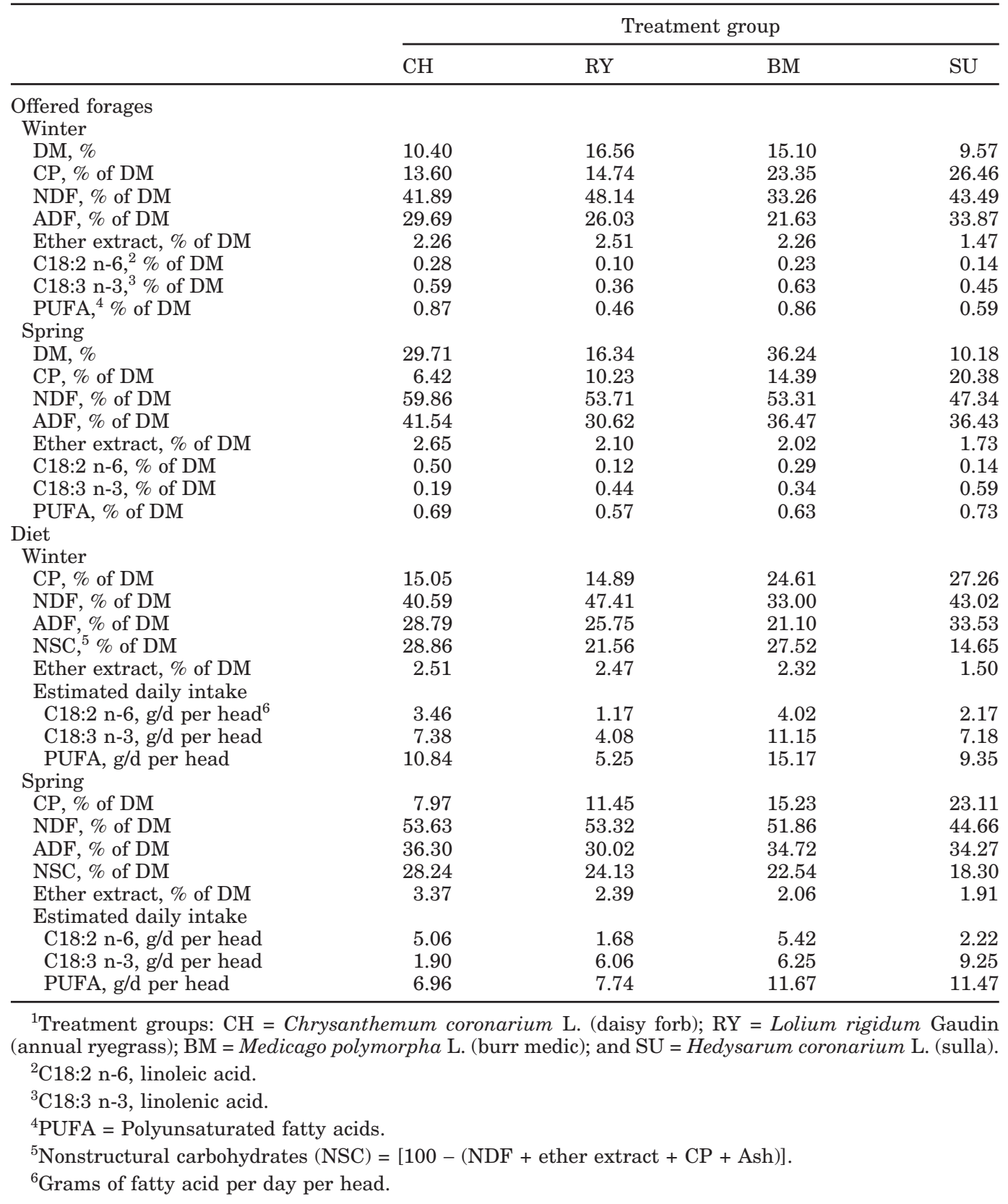

1989). Fatty acids were quantified and identified as detailed below for milk and cheese.

The chemical composition of forages on offer and diet is reported in Table 1. Chemical composition of diet was determined by difference between the composition of offered forages and that of corresponding orts.

\section{Animals and Animal Management}

The experiment was conducted in compliance with the principles and specific guidelines on animal care and welfare as required by Italian law (Gazzetta Ufficiale, DL no.116, January 27, 1992).

Thirty-two lactating mature Sarda ewes with previous experience of grazing the forages under study were blocked into 8 homogeneous groups by BW (mean \pm $\mathrm{SEM}=44.65 \pm 0.68$ and $45.84 \pm 0.90$ in winter and spring, respectively), BCS (mean $\pm \mathrm{SEM}=2.52 \pm 0.02$ and $2.59 \pm 0.03$ in winter and spring, respectively; Russel et al., 1969), and milk yield (1646 \pm 51 and $1400 \pm 51$ $\mathrm{mL}$ ). These animals were at different lactation stages during the winter and spring experimental periods (49 
$\pm 1 \mathrm{DIM}$ in winter, and $90 \pm 4 \mathrm{DIM}$ in spring). The sheep were randomly allocated to the feeding treatments (experimental groups $\mathrm{CH}, \mathrm{RY}, \mathrm{BM}$, and SU) such that there were 2 replicate groups per experimental group (4 ewes per replicate group). The replicate groups were housed in pens. The forages were cut twice daily and offered ad libitum in 4 meals daily. Water was always available to the animals.

Intake of herbage for each replicate group (expressed as grams of DM) was measured daily by weighing the amounts offered and the corresponding orts adjusted for their respective DM proportion. Body weight for each replicate group was measured at the same time of the day at the beginning and end of each experimental period.

The sheep that were used in the winter experimental period were re-randomized before being allocated to the experimental treatments in spring.

\section{Milk Yield and Milk Composition}

Milk yield from of each experimental group was measured during the last $3 \mathrm{~d}$ of each experimental period, and samples of milk were collected to determine fat matter (Gerber method), total nitrogen (Kjeldahl method), lactose (infrared method, Combifoss 4000 FOSS, Hillerød, Denmark), and fatty acids composition.

\section{Fatty Acids Composition}

Milk fat was extracted according to the Röse-Gottlieb method (using ethanol and hexane as extraction solvent mixture), and fatty acid methyl esters were obtained according to Chin et al. (1992). Separation and quantification of the methyl esters were carried out using a gas chromatograph (Varian 3600; Varian, Harbor City, CA), equipped with a split/splitless injector and a flameionization detector. The methyl ester separation was carried out on capillary column SP2560 $(100 \mathrm{~m} \times 0.25$ $\mathrm{mm}$ i.d., $0.25 \mu \mathrm{m}$ of phase; Supelco Inc., Bellefonte, PA) using helium as the carrier gas $(331 \mathrm{kPa})$. The injector and detector temperature was set at $290^{\circ} \mathrm{C}$. The injection was done in split mode with 1:100 split-ratio. The temperature of the column was initially at $75^{\circ} \mathrm{C}$ for 1.5 min, then increased to $190^{\circ} \mathrm{C}$ at $8^{\circ} \mathrm{C} / \mathrm{min}$, held at this temperature for $25 \mathrm{~min}$, then increased again to $230^{\circ} \mathrm{C}$ at $15^{\circ} \mathrm{C} / \mathrm{min}$, and held for a further $4.5 \mathrm{~min}$ at $230^{\circ} \mathrm{C}$. The results were analyzed by the software Star system 4.5 (Varian). Each fatty acid was identified with reference to the retention time of the standards (SigmaAldrich, St. Louis, MO) and quantified with respect to the following internal standards: C5:0 (C4:0-C8:0), C13:0 (C10:0-C17:0), and C19:0 (C18:0-C18:3). The concentration of each internal standard added to the sample was $170 \mathrm{mg} / \mathrm{g}$ of fat.
The fatty acid composition of 1-d and 60-d-old cheeses was determined. Four grams of sample were homogenized in $6 \mathrm{~g}$ of deionized water using an Ultraturrax $\mathrm{T}$ 25 basic blender (Ultra Turrax; IKA-WERKE, Staufen, Germany) at 13,500 rpm. Fatty acids extraction, methyl esters preparation, separation, identification, and quantification were performed as previously described for milk.

\section{Cheese Making}

In the last $3 \mathrm{~d}$ of each experimental period, the milk of each experimental group was collected and processed into cheese using a cheese-making pilot plant made by INRA (Poligny, France). Typically, the milks were made into cheese simultaneously using 4 identical 11-L cheese vats. On each cheese-making occasion, one semihard uncooked cheese type per experimental group was manufactured for analytical purposes, in loaves weighing about $1 \mathrm{~kg}$ each. Cheeses were ripened for 2 mo at $12^{\circ} \mathrm{C}$ and $85 \%$ relative humidity.

\section{Calculations and Statistical Analyses}

Before analyses, the data on fatty acid composition were processed to compute the content of short-chain fatty acids (SCFA; C4:0-C10:0), medium-chain fatty acids (MCFA; C12:0-C16:1), long-chain fatty acids (LCFA; C17:0-C18:3), monounsaturated fatty acids, and polyunsaturated fatty acids. Moreover, ratios were calculated including the ratio of vaccenic acid (VA) to rumenic acid (CLA) and C14:0/C14:1 ( $\Delta^{9}$-desaturase activity index). Finally, the atherogenicity index was calculated according to Chilliard et al. (2003), as follows: $(\mathrm{C} 12: 0+4 \times \mathrm{C} 14: 0+\mathrm{C} 16: 0) /($ monounsaturated + polyunsaturated fatty acids).

Statistical treatment of the data was performed using the SPSS 11.5.1 software (SPSS Inc., Chicago, IL). The results of the animal performances and chemical composition of milk and fatty acids composition of milk and cheeses were submitted to ANOVA $(\alpha=0.05)$. The model included the effects of forage species (F, 4 levels). The comparison between means was performed using Tukey's significant difference test. The data concerning the fatty acid composition of milk, 1-d-old cheeses, and 60-d-old cheeses were grouped and submitted to a stepwise discriminant analysis to determine the fatty acids that are the most useful for classifying the samples by forage species. Wilk's $\Lambda$ was used as the statistical selection criterion to determine the addition or removal of variables in the discriminant function. Before multivariate procedures, variables were scaled to zero mean and unit variance. For better visualization, the canonical scores were plotted in the discriminant space. 
Table 2. Animal performances and milk composition of lactating sheep fed with fresh forages of Chrysanthemum coronarium $(\mathrm{CH})$, annual ryegrass $(\mathrm{RY})$, burr medic $(\mathrm{BM})$, or sulla (SU) in experiment 1 (winter period). ${ }^{1}$

\begin{tabular}{lccccc}
\hline & \multicolumn{4}{c}{ Treatments } & SEM \\
\cline { 2 - 5 } & $\mathrm{CH}$ & $\mathrm{RY}$ & $\mathrm{BM}$ & $\mathrm{SU}$ & \\
\hline Herbage intake, g of DM & $1248^{\mathrm{bc}}$ & $1139^{\mathrm{c}}$ & $1772^{\mathrm{a}}$ & $1580^{\mathrm{ab}}$ & 98 \\
BW changes, kg/period & -0.78 & -0.86 & -2.06 & 0.43 & 0.40 \\
Milk yield, mL & $1353^{\mathrm{c}}$ & $1140^{\mathrm{d}}$ & $1710^{\mathrm{b}}$ & $2040^{\mathrm{a}}$ & 104 \\
Fat, \% & $5.17^{\mathrm{b}}$ & $5.98^{\mathrm{a}}$ & $5.49^{\mathrm{ab}}$ & $4.93^{\mathrm{b}}$ & 0.14 \\
Protein, \% & $4.07^{\mathrm{b}}$ & $5.03^{\mathrm{a}}$ & $4.49^{\mathrm{b}}$ & $5.12^{\mathrm{a}}$ & 0.14 \\
Lactose, \% & 4.57 & 4.82 & 4.49 & 4.93 & 0.10 \\
\hline a,b,c,d Forage effect: means within row with different superscripts differ $(P<0.05)$. & \\
\multicolumn{1}{l}{${ }^{1}$ Herbage intake (forage offered - orts) and BW changes were determined for each replicate group; milk } \\
yield and milk composition were determined for each experimental group.
\end{tabular}

\section{RESULTS AND DISCUSSION}

\section{Animal Performance}

Experiment 1. Table 2 shows the animal performances and milk composition of the experimental groups in winter. The herbage intake was higher in BM and $\mathrm{SU}$ than in RY and $\mathrm{CH}$ groups $(P<0.05)$. Body weight increased only in the SU group $(P<0.05$, Table 2 ). The change from a pre-experimental mixed diet inclusive of herbage, hay, and concentrate to an exclusively herbage-based diet probably brought about an increased passage rate and a decreased fill of the digestive tract. This could partially explain the important BW losses that occurred in almost all groups.

The SU-based feeding regimens resulted in better milk performance (Table 2). Milk yield differed significantly in all groups according to the following order: $\mathrm{SU}>\mathrm{BM}>\mathrm{CH}>\mathrm{RY}(P<0.05)$. During winter, $\mathrm{BM}$ had significantly lower milk yield and higher negative BW change $(P<0.05)$ compared with SU, even if the DM intake was higher in the former than in the latter group. This observation is probably due to the occurrence of high levels of isoflavones in burr medic forage. Isoflavones can negatively affect digestibility and hence, the nutritional value of forage (Reed et al., 2000).

The forage species also influenced milk composition. Milk fat content was significantly higher in RY than in $\mathrm{CH}$ and SU groups $(P<0.05)$. This could be related to the dilution effect, particularly in the SU group. Milk protein was higher in SU and RY than in the other groups $(P<0.05)$. For the RY group, this finding can be partially explained as a dilution effect. For the SU group, there might be another underlying reason: the SU group displayed a high forage intake and probably experienced a higher intake of energy than the other groups. Energy balance is linearly related to milk protein content in dairy sheep. Nevertheless, an effect of $\mathrm{CP}$ intake higher in SU-fed sheep than in the counter- parts cannot be excluded. Milk lactose was not affected by forage species $(P>0.05)$.

Experiment 2. Animal performances and milk composition of the experimental groups in spring are reported in Table 3. In spring, as in winter, the herbage intake was higher in BM and in SU than in RY and $\mathrm{CH}$ groups $(P<0.05)$. Herbage intake was very low in the CH group. Sulas et al. (1999) found higher herbage intake of Chrysanthemum coronarium grazed by Sarda sheep during flowering, and Avondo et al. (2002) indicated this forb in the list of the most palatable species for dairy sheep grazing native Mediterranean pastures. A major reason for the discrepancy between the results of the present study and the above cited references is that the stall-fed sheep in this study were probably unable to express their selectivity that they show when grazing.

As expected based on forage intake, BW change was more negative in $\mathrm{CH}$ than in the other groups $(P<0.05)$.

The SU-based feeding regimens resulted in better milk performance in spring. Milk yield differed significantly in all groups according to the following order: $\mathrm{SU}>\mathrm{RY}>\mathrm{BM}>\mathrm{CH}(P<0.05$, Table 3$)$. Milk fat content in the $\mathrm{BM}$ and $\mathrm{RY}$ groups was significantly higher than in the SU group. As in experiment 1, milk protein content was higher in SU and RY than in the other groups $(P<0.05)$. The milk lactose content was higher in SU $(P<0.05)$ and in RY groups than in the other treatment groups.

\section{Fatty Acid Composition of Milk}

Experiment 1. In Table 4, the results of milk fatty acids composition in winter are summarized. The effect of the forage species was significant for all considered milk fatty acids $(P<0.05)$ except for $\mathrm{C} 4: 0$ and $\mathrm{C} 17: 0$.

The percentage of SCFA in milk fat was significantly higher in SU than in the other groups $(P<0.05)$, whereas $\mathrm{CH}, \mathrm{RY}$, and $\mathrm{BM}$ milks did not differ signifi- 
Table 3. Animal performances and milk composition of lactating sheep fed with fresh forages of Chrysanthemum coronarium $(\mathrm{CH})$, annual ryegrass $(\mathrm{RY})$, burr medic (BM), or sulla (SU) in experiment 2 (spring period). ${ }^{1}$

\begin{tabular}{lccccc}
\hline & \multicolumn{4}{c}{ Treatments } & SEM \\
\cline { 2 - 5 } & $\mathrm{CH}$ & $\mathrm{RY}$ & $\mathrm{BM}$ & $\mathrm{SU}$ & 120 \\
\hline Herbage intake, g of DM & $1008^{\mathrm{c}}$ & $1362^{\mathrm{bc}}$ & $1857^{\mathrm{a}}$ & $1565^{\mathrm{ab}}$ & $-1.71^{\mathrm{b}}$ \\
BW changes, kg/period & $-6.72^{\mathrm{a}}$ & $-1.32^{\mathrm{b}}$ & $-0.99^{\mathrm{b}}$ & 0.20 \\
Milk yield, mL & $637^{\mathrm{d}}$ & $1170^{\mathrm{b}}$ & $863^{\mathrm{c}}$ & $1833^{\mathrm{a}}$ & 137 \\
Fat, \% & $5.71^{\mathrm{ab}}$ & $5.96^{\mathrm{a}}$ & $6.02^{\mathrm{a}}$ & $5.40^{\mathrm{b}}$ & 0.08 \\
Protein, \% & $4.38^{\mathrm{b}}$ & $4.83^{\mathrm{a}}$ & $4.39^{\mathrm{b}}$ & $4.99^{\mathrm{a}}$ & 0.08 \\
Lactose, \% & $4.33^{\mathrm{b}}$ & $4.87^{\mathrm{a}}$ & $4.38^{\mathrm{b}}$ & $5.08^{\mathrm{a}}$ & 0.10 \\
\hline
\end{tabular}

a,b,c,d Forage effect: means within row with different superscripts differ $(P<0.05)$.

${ }^{1}$ Herbage intake (forage offered - orts) and BW changes were determined for each replicate group; milk yield and milk composition were determined for each experimental group.

cantly from each other, even if $\mathrm{CH}$ milk tended to show a lower percentage of SCFA $(P>0.05)$. The $\mathrm{CH}$ milk also showed a lower $(P<0.05)$ content of MCFA compared with SU, RY, and BM milks (which did not differ significantly among themselves). Fatty acids with chain length less than 16 carbon atoms arise from mammary synthesis (de novo synthesis). De novo synthesis is positively affected by the energy balance of the ruminant for body maintenance and milk secretion (Chilliard et al., 2001). Indeed, SU-fed sheep probably experienced better energy balance than sheep in other groups because they showed the highest milk yield and positive BW changes.

Long-chain fatty acids showed the opposite trend to SCFA and MCFA. This class of fatty acids differed significantly, with the highest value being in $\mathrm{CH}$ milk,

Table 4. Milk fatty acid composition in lactating sheep fed with fresh forages of Chrysanthemum coronarium $(\mathrm{CH})$, annual ryegrass $(\mathrm{RY})$, burr medic $(\mathrm{BM})$, or sulla (SU) in experiment 1 (winter period).

\begin{tabular}{|c|c|c|c|c|c|}
\hline \multirow{2}{*}{$\begin{array}{l}\text { Fatty acid, }{ }^{1} \mathrm{~g} / 100 \mathrm{~g} \\
\text { of fatty acids }\end{array}$} & \multicolumn{4}{|c|}{ Treatments } & \multirow[b]{2}{*}{ SEM } \\
\hline & $\mathrm{CH}$ & RY & $\mathrm{BM}$ & SU & \\
\hline $\mathrm{C} 4: 0$ & 5.06 & 4.65 & 4.55 & 4.91 & 0.09 \\
\hline C6:0 & $2.43^{\mathrm{b}}$ & $2.54^{\mathrm{b}}$ & $2.65^{b}$ & $3.16^{\mathrm{a}}$ & 0.09 \\
\hline C8:0 & $1.59^{\mathrm{b}}$ & $1.98^{\mathrm{b}}$ & $1.88^{\mathrm{b}}$ & $2.55^{\mathrm{a}}$ & 0.11 \\
\hline C10:0 & $6.90^{\mathrm{c}}$ & $9.85^{\mathrm{b}}$ & $8.75^{\mathrm{bc}}$ & $13.91^{\mathrm{a}}$ & 0.80 \\
\hline C12:0 & $3.40^{\mathrm{c}}$ & $4.59^{\mathrm{b}}$ & $4.03^{\mathrm{bc}}$ & $6.52^{\mathrm{a}}$ & 0.37 \\
\hline C14:0 & $10.08^{\mathrm{b}}$ & $10.75^{\mathrm{ab}}$ & $10.62^{\mathrm{ab}}$ & $11.74^{\mathrm{a}}$ & 0.22 \\
\hline C14:1 cis -9 & $0.14^{\mathrm{c}}$ & $0.19^{\mathrm{a}}$ & $0.18^{\mathrm{ab}}$ & $0.15^{\mathrm{bc}}$ & 0.01 \\
\hline $\mathrm{C} 15: 0$ & $1.23^{\mathrm{b}}$ & $1.26^{\mathrm{b}}$ & $1.36^{\mathrm{ab}}$ & $1.52^{\mathrm{a}}$ & 0.04 \\
\hline C16:0 & $20.94^{\mathrm{b}}$ & $23.94^{\mathrm{a}}$ & $23.86^{\mathrm{a}}$ & $22.45^{\mathrm{ab}}$ & 0.41 \\
\hline C16:1 cis -9 & $0.59^{b}$ & $0.77^{\mathrm{a}}$ & $0.72^{\mathrm{a}}$ & $0.48^{\mathrm{c}}$ & 0.04 \\
\hline $\mathrm{C} 17: 0$ & 0.78 & 0.70 & 0.69 & 0.74 & 0.02 \\
\hline C18:0 & $10.80^{\mathrm{a}}$ & $10.45^{\mathrm{ab}}$ & $9.15^{\mathrm{c}}$ & $9.61^{\mathrm{bc}}$ & 0.22 \\
\hline C18:1 trans -11 & $4.00^{\mathrm{a}}$ & $2.08^{\mathrm{c}}$ & $3.24^{b}$ & $3.18^{\mathrm{b}}$ & 0.21 \\
\hline C18:1 cis-9 & $25.36^{\mathrm{a}}$ & $21.99^{\mathrm{a}}$ & $21.48^{\mathrm{a}}$ & $13.28^{\mathrm{b}}$ & 1.43 \\
\hline C18:2 n-6 & $2.74^{\mathrm{a}}$ & $1.59^{\mathrm{b}}$ & $2.35^{\mathrm{a}}$ & $1.58^{\mathrm{b}}$ & 0.16 \\
\hline C18:3 n-3 & $1.62^{\mathrm{c}}$ & $1.47^{\mathrm{d}}$ & $2.19^{\mathrm{b}}$ & $2.98^{\mathrm{a}}$ & 0.18 \\
\hline $\mathrm{C} 18: 2 \mathrm{c}-9, \mathrm{t}-11$ & $2.35^{\mathrm{a}}$ & $1.20^{\mathrm{b}}$ & $2.30^{\mathrm{a}}$ & $1.25^{\mathrm{b}}$ & 0.17 \\
\hline SCFA & $15.98^{\mathrm{b}}$ & $19.03^{\mathrm{b}}$ & $17.83^{\mathrm{b}}$ & $24.53^{\mathrm{a}}$ & 1.01 \\
\hline MCFA & $36.37^{\mathrm{b}}$ & $41.51^{\mathrm{a}}$ & $40.77^{\mathrm{a}}$ & $42.87^{\mathrm{a}}$ & 0.80 \\
\hline LCFA & $47.64^{\mathrm{a}}$ & $39.47^{\mathrm{b}}$ & $41.40^{\mathrm{ab}}$ & $32.60^{\mathrm{c}}$ & 1.73 \\
\hline PUFA & $6.70^{\mathrm{a}}$ & $4.25^{\mathrm{c}}$ & $6.84^{\mathrm{a}}$ & $5.80^{\mathrm{b}}$ & 0.32 \\
\hline VA/CLA ratio & $1.71^{\mathrm{b}}$ & $1.75^{\mathrm{b}}$ & $1.41^{\mathrm{b}}$ & $2.58^{\mathrm{a}}$ & 0.14 \\
\hline$\Delta^{9}$-desaturase index & $0.014^{\mathrm{bc}}$ & $0.018^{\mathrm{a}}$ & $0.017^{\mathrm{ab}}$ & $0.013^{\mathrm{c}}$ & 0.001 \\
\hline Atherogenicity index & $1.76^{\mathrm{c}}$ & $2.49^{\mathrm{b}}$ & $2.17^{\mathrm{bc}}$ & $3.32^{\mathrm{a}}$ & 0.19 \\
\hline
\end{tabular}

${ }^{\text {a,b,c }}$ Forage effect: means within row with different superscripts differ $(P<0.05)$.

${ }^{1}$ Fatty acids: C4:0, butyric acid; C6:0, caproic acid; C8:0, caprylic acid; C10:0, capric acid; C12:0, lauric acid; C14:0, myristic acid; C14:1 cis-9, myristoleic acid; C15:0, pentadecanoic acid; C16:0, palmitic acid; C16:1 cis-9, palmitoleic acid; C17:0, margaric acid; C18:0, stearic acid; C18:1 trans-11, vaccenic acid; C18:1 cis-9, oleic acid; C18:2 n-6, linoleic acid; C18:3 n-3, linolenic acid; C18:2 c-9, t-11, rumenic acid; SCFA, shortchain fatty acids; MCFA, medium-chain fatty acids; LCFA, long-chain fatty acids; PUFA, polyunsaturated fatty acids; VA/CLA, vaccenic acid to rumenic acid ratio. 
intermediate in RY and $\mathrm{BM}$, and the lowest in SU milk $(P<0.05)$.

The present study has been particularly focused on C18:2 cis-9,trans-11 (rumenic acid), C18:1 trans-11 (VA), and on their ruminal precursors, C18:2 n-6 (linoleic acid) and C18:3 n-3 (linolenic acid). Rumenic acid, the main isomer of CLA, is an intermediate in rumen biohydrogenation of linoleic acid, whereas VA is a common intermediate in the biohydrogenation of both linoleic and linolenic acids. Because the reduction of VA in the rumen is generally rate limiting for the complete hydrogenation of unsaturated $\mathrm{C} 18$ fatty acids, there is often a ruminal accumulation of this acid (Griinari and Bauman, 1999). As well as rumenic acid, VA is then taken up in the gut and desaturated to rumenic acid by $\Delta^{9}$-desaturase in the mammary gland. This is regarded as the most important source of milk rumenic acid (Griinari and Bauman, 1999).

In winter (Table 4), the content of linoleic acid in milk fat was significantly higher in $\mathrm{CH}$ and $\mathrm{BM}$ than in RY and SU groups $(P<0.05)$. In contrast, linolenic acid differed significantly between milks of all groups, which were ranked as follows: $\mathrm{SU}>\mathrm{BM}>\mathrm{CH}>\mathrm{RY}(P$ $<0.05$ ). Linoleic and linolenic acids are of dietary origin; they are not synthesized by ruminant tissue, and their concentration in milk is dependent on the amount that flows out of the rumen. Milk from $\mathrm{CH}$-fed sheep showed the highest concentration of linoleic acid as expected due to the higher concentration of this acid in the offered $\mathrm{CH}$ forage (Table 1). On the contrary, SU milk showed the highest content of linolenic acid of all groups. A similar finding was reported by Piredda et al. (2002), who found that the proportion of linolenic acid in milk fat was directly related to the time allocation on sulla pasture, and hence, to sulla intake (Molle et al., 2003).

In winter (Table 4), the content of VA was significantly higher in $\mathrm{CH}$ than in RY milk, and intermediate in BM and SU. The $\mathrm{CH}$ and BM milks showed a significantly higher content of rumenic acid than did the SU and RY milks $(P<0.05)$. The highest percentage of VA and rumenic acid in $\mathrm{CH}$ milk was probably due to the higher content of ruminal precursors in $\mathrm{CH}$ forage with specific reference to linoleic acid (Table 1). The content of rumenic acid and VA in SU and RY milk was slightly lower in this study compared with the results found by Piredda et al. (2002) in a grazing experiment. This was expected because, firstly, a decline in the level of rumenic acid precursors was previously demonstrated during haymaking (Offer, 2002) and secondly, grazing ewes are able to express their selectivity toward the most nutritive parts of the plant (i.e., leaves, rich in rumenic acid precursors) much more than their stallfed counterparts (Molle et al., 2002).
Pooling the data from all experimental groups, a positive relationship was found between VA and rumenic acid in milk fat $\left(R^{2}=0.50, P<0.01\right)$. Moreover, a positive relationship was found between the intake of ether extract and rumenic acid content in milk fat $\left(\mathrm{R}^{2}=0.55\right.$, $P<0.01$ ).

The $\Delta^{9}$-desaturase activity index (calculated as C14:1/C14:0) and the VA/CLA ratio tended to differ from the results of literature on dairy cattle (Lock and Garnsworthy, 2003) with a trend toward higher VA/ CLA and lower C14:1/C14:0 in this study, particularly for the SU-fed sheep (Table 4). The discrepancy between cow and sheep milk could be due to an effect of the animal species on the $\Delta^{9}$-desaturase activity in the mammary gland.

The atherogenicity index (Table 4) characterizes the atherogenicity of dietary fat; fat with high atherogenicity index value is assumed more detrimental to the human health. In the human diet, lipids (particularly the saturated fatty acids) are known to contribute to coronary heart disease (Williams, 2000). On the contrary, some unsaturated fatty acids in milk have a protective effect against the risk of cardiovascular disease, including rumenic acid, monounsaturated fatty acids (in particular oleic acid), and polyunsaturated fatty acids. In this study, we found a significant effect of forage species on atherogenicity index value. In particular, this index was the lowest in $\mathrm{CH}$ milk, highest in SU milk, and intermediate in RY and BM milks $(P<$ 0.05). This was probably related to the much higher level of unsaturated fatty acids and lower level of saturated fatty acids in the milk fat of sheep fed CH compared with the other treatment groups.

Experiment 2. Table 5 shows milk fatty acids composition in spring. The effect of forage species was significant for all considered fatty acids. The content of SCFA differed significantly in all milks according to the following order: $\mathrm{SU}>\mathrm{RY}>\mathrm{BM}>\mathrm{CH}(P<0.05)$. With reference to MCFA percentage, SU and RY milks had the highest content and differed significantly from $\mathrm{CH}$, whereas BM was intermediate. In spring, as seen in winter during the vegetative phase of the forages (experiment 1), the content of SCFA and MCFA was the highest in SU milk because SU-fed sheep probably experienced a better energy balance than the other groups. The percentage of SCFA and MCFA in milk was intermediate in RY and BM, and the lowest in $\mathrm{CH}$. A similar ranking was observed also in the milk yield of these groups.

During spring, LCFA differed significantly in all milks according to the following order: $\mathrm{CH}>\mathrm{BM}>\mathrm{RY}$ $>$ SU. Long-chain fatty acids with 16 or more carbon atoms are sourced either in the diet or because of body fat mobilization. In particular, the milk fat content of 
Table 5. Milk fatty acid composition in lactating sheep fed with fresh forages of Chrysanthemum coronarium $(\mathrm{CH})$, annual ryegrass (RY), burr medic (BM), or sulla (SU) in experiment 2 (spring period).

\begin{tabular}{|c|c|c|c|c|c|}
\hline \multirow{2}{*}{$\begin{array}{l}\text { Fatty acid, }{ }^{1} \mathrm{~g} / 100 \mathrm{~g} \\
\text { of fatty acids }\end{array}$} & \multicolumn{4}{|c|}{ Treatments } & \multirow[b]{2}{*}{ SEM } \\
\hline & $\mathrm{CH}$ & $\mathrm{RY}$ & $\mathrm{BM}$ & SU & \\
\hline $\mathrm{C} 4: 0$ & $3.24^{\mathrm{c}}$ & $4.70^{\mathrm{a}}$ & $3.91^{b}$ & $4.78^{\mathrm{a}}$ & 0.20 \\
\hline C6:0 & $0.85^{\mathrm{d}}$ & $2.63^{\mathrm{b}}$ & $1.70^{\mathrm{c}}$ & $2.94^{\mathrm{a}}$ & 0.25 \\
\hline C8:0 & $0.50^{\mathrm{d}}$ & $1.80^{\mathrm{b}}$ & $1.02^{\mathrm{c}}$ & $2.18^{\mathrm{a}}$ & 0.20 \\
\hline C10:0 & $1.90^{\mathrm{d}}$ & $8.99^{\mathrm{b}}$ & $4.81^{\mathrm{c}}$ & $11.84^{\mathrm{a}}$ & 1.15 \\
\hline C12:0 & $1.48^{\mathrm{d}}$ & $4.18^{\mathrm{b}}$ & $2.51^{\mathrm{c}}$ & $5.44^{\mathrm{a}}$ & 0.46 \\
\hline C14:0 & $5.53^{\mathrm{c}}$ & $10.86^{\mathrm{a}}$ & $9.01^{\mathrm{b}}$ & $11.85^{\mathrm{a}}$ & 0.73 \\
\hline $\mathrm{C} 14: 1$ cis-9 & $0.10^{\mathrm{b}}$ & $0.20^{\mathrm{a}}$ & $0.19^{\mathrm{a}}$ & $0.17^{\mathrm{a}}$ & 0.01 \\
\hline C15:0 & $1.11^{\mathrm{b}}$ & $1.38^{\mathrm{a}}$ & $1.53^{\mathrm{a}}$ & $1.42^{\mathrm{a}}$ & 0.05 \\
\hline $\mathrm{C} 16: 0$ & $18.75^{\mathrm{b}}$ & $24.74^{\mathrm{a}}$ & $23.10^{\mathrm{a}}$ & $24.68^{\mathrm{a}}$ & 0.76 \\
\hline C16:1 cis-9 & $0.78^{\mathrm{a}}$ & $0.76^{\mathrm{a}}$ & $0.78^{\mathrm{a}}$ & $0.53^{\mathrm{b}}$ & 0.03 \\
\hline $\mathrm{C} 17: 0$ & $0.96^{\mathrm{a}}$ & $0.76^{\mathrm{b}}$ & $0.89^{\mathrm{a}}$ & $0.69^{\mathrm{b}}$ & 0.03 \\
\hline C18:0 & $13.31^{\mathrm{a}}$ & $10.96^{\mathrm{bc}}$ & $12.11^{\mathrm{b}}$ & $10.29^{\mathrm{c}}$ & 0.36 \\
\hline C18:1 trans -11 & $3.13^{\mathrm{a}}$ & $2.52^{\mathrm{ab}}$ & $2.25^{\mathrm{b}}$ & $2.36^{\mathrm{b}}$ & 0.12 \\
\hline C18:1 cis-9 & $41.30^{\mathrm{a}}$ & $21.14^{\mathrm{c}}$ & $29.89^{\mathrm{b}}$ & $14.81^{\mathrm{d}}$ & 3.02 \\
\hline C18:2 n-6 & $3.48^{\mathrm{a}}$ & $1.54^{\mathrm{d}}$ & $2.82^{\mathrm{b}}$ & $1.75^{\mathrm{c}}$ & 0.24 \\
\hline C18:3 n-3 & $1.26^{\mathrm{c}}$ & $1.44^{\mathrm{c}}$ & $1.84^{\mathrm{b}}$ & $3.15^{\mathrm{a}}$ & 0.23 \\
\hline C18:2 c-9, t-11 & $2.33^{\mathrm{a}}$ & $1.43^{\mathrm{bc}}$ & $1.65^{\mathrm{b}}$ & $1.12^{\mathrm{c}}$ & 0.14 \\
\hline SCFA & $6.48^{\mathrm{d}}$ & $18.12^{\mathrm{b}}$ & $11.43^{\mathrm{c}}$ & $21.74^{\mathrm{a}}$ & 1.78 \\
\hline MCFA & $27.76^{\mathrm{c}}$ & $42.10^{\mathrm{a}}$ & $37.11^{\mathrm{b}}$ & $44.08^{\mathrm{a}}$ & 1.92 \\
\hline LCFA & $65.75^{\mathrm{a}}$ & $39.78^{\mathrm{c}}$ & $51.45^{\mathrm{b}}$ & $34.18^{\mathrm{d}}$ & 3.66 \\
\hline PUFA & $7.06^{\mathrm{a}}$ & $4.41^{\mathrm{c}}$ & $6.31^{\mathrm{b}}$ & $6.02^{\mathrm{b}}$ & 0.30 \\
\hline VA/CLA ratio & $1.34^{\mathrm{c}}$ & $1.76^{\mathrm{b}}$ & $1.36^{\mathrm{c}}$ & $2.11^{\mathrm{a}}$ & 0.10 \\
\hline$\Delta^{9}$-desaturase index & $0.019^{\mathrm{a}}$ & $0.018^{\mathrm{ab}}$ & $0.021^{\mathrm{a}}$ & $0.014^{b}$ & 0.001 \\
\hline Atherogenicity index & $0.81^{\mathrm{d}}$ & $2.50^{\mathrm{b}}$ & $1.57^{\mathrm{c}}$ & $3.24^{\mathrm{a}}$ & 0.28 \\
\hline
\end{tabular}

a,b,c,d Forage effect: means within row with different superscripts differ $(P<0.05)$.

${ }^{1}$ Fatty acids: $\mathrm{C} 4: 0$, butyric acid; $\mathrm{C} 6: 0$, caproic acid; C8:0, caprylic acid; C10:0, capric acid; C12:0, lauric acid; C14:0, myristic acid; C14:1 cis-9, myristoleic acid; C15:0, pentadecanoic acid; C16:0, palmitic acid; C16:1 cis-9, palmitoleic acid; C17:0, margaric acid; C18:0, stearic acid; C18:1 trans-11, vaccenic acid; C18:1 cis-9, oleic acid; C18:2 n-6, linoleic acid; C18:3 n-3, linolenic acid; C18:2 c-9, t-11, rumenic acid; SCFA, shortchain fatty acids; MCFA, medium-chain fatty acids; LCFA, long-chain fatty acids; PUFA, polyunsaturated fatty acids; VA/CLA, vaccenic acid to rumenic acid ratio.

C18:0 (stearic acid) and C18:1 (oleic acid) are usually associated with the mobilization of fat depots (Chilliard et al., 2003). The high concentration of these fatty acids in $\mathrm{CH}$ milk, particularly in spring (Table 5), could be related to the high intensity of body fat mobilization that probably occurred in these animals as suggested by the marked BW losses. Because some LCFA are potent inhibitors of mammary FA synthesis (Chilliard et al., 2000), the highest content of LCFA in $\mathrm{CH}$ milk could partially explain its low content of SCFA.

If we compare the experimental period results, SCFA content decreased in $\mathrm{CH}$ and $\mathrm{BM}$ milk in spring compared with winter. The content of MCFA also decreased, whereas LCFA increased. This is in agreement with a probable drop in the energy intake experienced by all groups during spring, particularly for $\mathrm{CH}$-fed sheep receiving forage with low $\mathrm{CP}$ and extremely high NDF contents (Table 1).

Among the LCFA (Table 5), linoleic acid differed significantly in all milks according to the following ranking: $\mathrm{CH}>\mathrm{BM}>\mathrm{SU}>\mathrm{RY}(P<0.05)$. Linolenic acid was the highest in SU milk, intermediate in BM milk, and the lowest in $\mathrm{CH}$ and $\mathrm{RY}$ milks $(P<0.05)$. The rumenic acid level was significantly higher in $\mathrm{CH}$ milk $(P<$ 0.05 ) respect to the other milks, and BM and SU milks differed between them. In addition, VA content was higher in $\mathrm{CH}$ than in the other milks but the difference was significant only with respect to BM and SU milks. This was probably due to the highest content of rumenic acid precursors in $\mathrm{CH}$ forage with specific reference to linoleic acid (Table 1). Among the possible reasons for the low content of rumenic acid in SU particularly in spring, 2 explanations may deserve particular attention: 1) the inhibitory effect of linolenic acid on $\Delta^{9}$ desaturase activity in the mammary gland (Sessler and Ntambi, 1998); and 2) the effect of condensed tannins on rumen biohydrogenation. As for the former, the index of the $\Delta^{9}$-desaturase activity was significantly lower in SU than in the other treatments (Table 5). The second possible explanation comes from a reduced yield (C18:1 trans-11) in the rumen due to the moderately high content of condensed tannins in this forage (up to $4 \% \mathrm{DM}$ according to Molle et al., 2003). These substances have indeed shown a relevant inhibitory effect on rumen bacteria metabolism (Makkar, 2001). Milk from SU-fed sheep showed the highest VA/CLA ratio $(P<0.05)$. 
Table 6. Fatty acid composition of 60-d-old cheeses obtained from sheep fed with fresh forages of Chrysanthemum coronarium (CH), annual ryegrass (RY), burr medic (BM), or sulla (SU) in experiment 1 (winter period).

\begin{tabular}{|c|c|c|c|c|c|}
\hline \multirow{2}{*}{$\begin{array}{l}\text { Fatty acid, }{ }^{1} \mathrm{~g} / 100 \mathrm{~g} \\
\text { of fatty acids }\end{array}$} & \multicolumn{4}{|c|}{ Treatments } & \multirow[b]{2}{*}{ SEM } \\
\hline & $\mathrm{CH}$ & RY & $\mathrm{BM}$ & $\mathrm{SU}$ & \\
\hline $\mathrm{C} 4: 0$ & 5.18 & 4.87 & 4.69 & 4.89 & 0.07 \\
\hline $\mathrm{C} 6: 0$ & $2.32^{\mathrm{b}}$ & $2.77^{\mathrm{ab}}$ & $2.59^{\mathrm{b}}$ & $3.27^{\mathrm{a}}$ & 0.12 \\
\hline C8:0 & $1.49^{\mathrm{b}}$ & $1.91^{\mathrm{b}}$ & $1.76^{\mathrm{b}}$ & $2.55^{\mathrm{a}}$ & 0.13 \\
\hline $\mathrm{C} 10: 0$ & $7.47^{\mathrm{b}}$ & $9.80^{\mathrm{b}}$ & $8.95^{\mathrm{b}}$ & $13.87^{\mathrm{a}}$ & 0.76 \\
\hline $\mathrm{C} 12: 0$ & $3.63^{\mathrm{b}}$ & $4.49^{\mathrm{b}}$ & $4.26^{\mathrm{b}}$ & $6.39^{\mathrm{a}}$ & 0.33 \\
\hline C14:0 & 10.42 & 10.28 & 10.56 & 11.20 & 0.17 \\
\hline C14:1 cis-9 & $0.14^{\mathrm{b}}$ & $0.18^{\mathrm{ab}}$ & $0.20^{\mathrm{a}}$ & $0.14^{\mathrm{b}}$ & 0.01 \\
\hline C15:0 & $1.32^{\mathrm{ab}}$ & $1.18^{\mathrm{b}}$ & $1.39^{\mathrm{a}}$ & $1.38^{\mathrm{a}}$ & 0.03 \\
\hline C16:0 & $22.11^{\mathrm{a}}$ & $21.48^{\mathrm{ab}}$ & $23.28^{\mathrm{a}}$ & $19.96^{\mathrm{b}}$ & 0.40 \\
\hline C16:1 cis-9 & $0.62^{\mathrm{b}}$ & $0.71^{\mathrm{ab}}$ & $0.74^{\mathrm{a}}$ & $0.43^{\mathrm{c}}$ & 0.04 \\
\hline $\mathrm{C} 17: 0$ & $0.86^{\mathrm{a}}$ & $0.62^{\mathrm{b}}$ & $0.66^{\mathrm{b}}$ & $0.62^{\mathrm{b}}$ & 0.03 \\
\hline C18:0 & $10.50^{\mathrm{ab}}$ & $10.97^{\mathrm{a}}$ & $9.31^{b}$ & $10.29^{\mathrm{ab}}$ & 0.22 \\
\hline $\mathrm{C} 18: 1$ trans -11 & $3.70^{\mathrm{a}}$ & $2.22^{\mathrm{b}}$ & $3.37^{\mathrm{a}}$ & $3.64^{\mathrm{a}}$ & 0.19 \\
\hline C18:1 cis-9 & $23.83^{\mathrm{a}}$ & $23.87^{\mathrm{a}}$ & $21.41^{\mathrm{a}}$ & $14.67^{\mathrm{b}}$ & 1.28 \\
\hline C18:2 n-6 & $2.71^{\mathrm{a}}$ & $1.76^{\mathrm{b}}$ & $2.46^{\mathrm{a}}$ & $1.85^{b}$ & 0.13 \\
\hline C18:3 n-3 & $1.59^{\mathrm{c}}$ & $1.57^{\mathrm{c}}$ & $2.23^{\mathrm{b}}$ & $3.33^{\mathrm{a}}$ & 0.22 \\
\hline C18:2 c-9, t-11 & $2.12^{\mathrm{a}}$ & $1.30^{\mathrm{b}}$ & $2.13^{\mathrm{a}}$ & $1.50^{\mathrm{b}}$ & 0.11 \\
\hline SCFA & $16.46^{\mathrm{b}}$ & $19.35^{\mathrm{b}}$ & $18.00^{\mathrm{b}}$ & $24.58^{\mathrm{a}}$ & 1.00 \\
\hline MCFA & 38.24 & 38.33 & 40.43 & 39.50 & 0.44 \\
\hline LCFA & $45.30^{\mathrm{a}}$ & $42.31^{\mathrm{ab}}$ & $41.58^{\mathrm{ab}}$ & $35.92^{\mathrm{b}}$ & 1.25 \\
\hline PUFA & $6.42^{\mathrm{a}}$ & $4.63^{\mathrm{b}}$ & $6.83^{\mathrm{a}}$ & $6.69^{\mathrm{a}}$ & 0.28 \\
\hline VA/CLA ratio & $1.76^{\mathrm{b}}$ & $1.71^{b}$ & $1.58^{\mathrm{b}}$ & $2.42^{\mathrm{a}}$ & 0.11 \\
\hline$\Delta^{9}$-desaturase index & $0.014^{\mathrm{bc}}$ & $0.018^{\mathrm{ab}}$ & $0.019^{\mathrm{a}}$ & $0.013^{\mathrm{c}}$ & 0.001 \\
\hline Atherogenicity index & $1.95^{\mathrm{b}}$ & $2.17^{\mathrm{ab}}$ & $2.15^{\mathrm{ab}}$ & $2.79^{\mathrm{a}}$ & 0.11 \\
\hline
\end{tabular}

a,b,c Forage effect: means within row with different superscripts differ $(P<0.05)$.

${ }^{1}$ Fatty acids: C4:0, butyric acid; C6:0, caproic acid; C8:0, caprylic acid; C10:0, capric acid; C12:0, lauric acid; C14:0, myristic acid; C14:1 cis-9, myristoleic acid; C15:0, pentadecanoic acid; C16:0, palmitic acid; C16:1 cis-9, palmitoleic acid; C17:0, margaric acid; C18:0, stearic acid; C18:1 trans-11, vaccenic acid; C18:1 cis-9, oleic acid; C18:2 n-6, linoleic acid; C18:3 n-3, linolenic acid; C18:2 c-9, t-11, rumenic acid; SCFA, shortchain fatty acids; MCFA, medium-chain fatty acids; LCFA, long-chain fatty acids; PUFA, polyunsaturated fatty acids; VA/CLA, vaccenic acid to rumenic acid ratio.

Rumenic and vaccenic acid contents tended to be higher in winter than spring, except for RY milk. These results partially confirm those found by Piredda et al. (2002), who found that milk vaccenic and rumenic acids in sheep grazing sulla and annual ryegrass decreased along with the grazing season.

A positive relationship between vaccenic acid and rumenic acid $\left(\mathrm{R}^{2}=0.67, P<0.001\right)$ was found in spring. Moreover, in this period, milk rumenic acid content showed a positive relationship with the intake of linoleic acid $\left(\mathrm{R}^{2}=0.42, P<0.01\right)$, whereas a negative relationship was found with the linolenic acid intake $\left(\mathrm{R}^{2}=\right.$ $0.90, P<0.001)$.

The atherogenicity index differed significantly in all milks; the lowest value was found in $\mathrm{CH}$ milk, the highest in SU milk, and intermediate in RY and BM milks $(P<0.05)$.

\section{Fatty Acid Composition of Cheese}

The fatty acid composition of 1-d-old (not shown) and 60-d-old ripened cheeses (Tables 6 and 7) did not differ from that of the corresponding milks in each considered period, as observed by Nudda et al. (2005). Therefore, the data of milk and cheeses were pooled before submitting them to the stepwise discriminant analysis whose statistics are reported in Table 8, together with the most important fatty acids contributing to the separation between plots. The effectiveness of the fatty acid composition to discriminate between dietary regimens for milk and cheeses obtained from ewes fed different forages, was confirmed by the canonical correlation and Wilks' $\Lambda$ values. Most of the total variation was explained by the first 2 discriminant functions; $75.8 \%$ of the total variance was explained by the first function, and $20.5 \%$ of the total variance was explained by the second one. All the milks and cheeses were classified correctly for the forage species (Figure 1). Function 1 determined the separation of $\mathrm{CH}, \mathrm{BM}$, and $\mathrm{SU}$ milks and cheeses. Variables contributing most to the separation were C14:0, oleic, and linolenic acid (Table 8). Function 2 determined the separation of RY from SU and, to some extent, of RY from $\mathrm{CH}$ and $\mathrm{BM}$ milks and cheeses (Figure 1). Linoleic acid and oleic acid mainly contributed to this separation (Table 8). 
Table 7. Fatty acid composition of 60-d-old cheeses obtained from sheep fed with fresh forages of Chrysanthemum coronarium $(\mathrm{CH})$, annual ryegrass (RY), burr medic (BM), or sulla (SU) in experiment 2 (spring period).

\begin{tabular}{|c|c|c|c|c|c|}
\hline \multirow{2}{*}{$\begin{array}{l}\text { Fatty acid, }{ }^{1} \mathrm{~g} / 100 \mathrm{~g} \\
\text { of fatty acids }\end{array}$} & \multicolumn{4}{|c|}{ Treatments } & \multirow[b]{2}{*}{ SEM } \\
\hline & $\mathrm{CH}$ & $\mathrm{RY}$ & $\mathrm{BM}$ & $\mathrm{SU}$ & \\
\hline $\mathrm{C} 4: 0$ & $3.24^{\mathrm{c}}$ & $4.56^{\mathrm{a}}$ & $4.11^{b}$ & $4.83^{\mathrm{a}}$ & 0.19 \\
\hline C6:0 & $0.80^{\mathrm{d}}$ & $2.57^{\mathrm{b}}$ & $1.65^{\mathrm{c}}$ & $2.91^{\mathrm{a}}$ & 0.25 \\
\hline $\mathrm{C} 8: 0$ & $0.41^{\mathrm{d}}$ & $1.74^{\mathrm{b}}$ & $0.95^{\mathrm{c}}$ & $2.11^{\mathrm{a}}$ & 0.20 \\
\hline $\mathrm{C} 10: 0$ & $1.93^{\mathrm{d}}$ & $8.94^{\mathrm{b}}$ & $4.81^{\mathrm{c}}$ & $11.83^{\mathrm{a}}$ & 1.15 \\
\hline $\mathrm{C} 12: 0$ & $1.47^{\mathrm{d}}$ & $4.14^{\mathrm{b}}$ & $2.67^{\mathrm{c}}$ & $5.36^{\mathrm{a}}$ & 0.45 \\
\hline C14:0 & $5.58^{\mathrm{c}}$ & $10.46^{\mathrm{a}}$ & $9.03^{\mathrm{b}}$ & $11.30^{\mathrm{a}}$ & 0.67 \\
\hline $\mathrm{C} 14: 1 \mathrm{cis}-9$ & $0.11^{\mathrm{b}}$ & $0.19^{\mathrm{a}}$ & $0.19^{\mathrm{a}}$ & $0.16^{\mathrm{a}}$ & 0.01 \\
\hline $\mathrm{C} 15: 0$ & $1.13^{\mathrm{b}}$ & $1.31^{\mathrm{ab}}$ & $1.55^{\mathrm{a}}$ & $1.31^{\mathrm{ab}}$ & 0.05 \\
\hline $\mathrm{C} 16: 0$ & $19.29^{\mathrm{b}}$ & $22.52^{\mathrm{a}}$ & $23.52^{\mathrm{a}}$ & $22.03^{\mathrm{a}}$ & 0.53 \\
\hline C16:1 cis -9 & $0.81^{\mathrm{a}}$ & $0.72^{\mathrm{a}}$ & $0.82^{\mathrm{a}}$ & $0.49^{\mathrm{b}}$ & 0.04 \\
\hline C17:0 & $1.00^{\mathrm{a}}$ & $0.68^{\mathrm{b}}$ & $0.93^{\mathrm{a}}$ & $0.61^{\mathrm{b}}$ & 0.05 \\
\hline C18:0 & $13.23^{\mathrm{a}}$ & $11.68^{\mathrm{b}}$ & $12.11^{\mathrm{ab}}$ & $11.00^{\mathrm{b}}$ & 0.28 \\
\hline C18:1 trans -11 & $3.17^{\mathrm{a}}$ & $2.67^{\mathrm{ab}}$ & $2.21^{\mathrm{b}}$ & $2.75^{\mathrm{ab}}$ & 0.12 \\
\hline C18:1 cis-9 & $40.99^{\mathrm{a}}$ & $23.22^{\mathrm{c}}$ & $29.39^{\mathrm{b}}$ & $16.64^{\mathrm{d}}$ & 2.74 \\
\hline $\mathrm{C} 18: 2 \mathrm{n}-6$ & $3.46^{\mathrm{a}}$ & $1.58^{\mathrm{d}}$ & $2.91^{\mathrm{b}}$ & $1.91^{\mathrm{c}}$ & 0.23 \\
\hline C18:3 n-3 & $1.24^{\mathrm{c}}$ & $1.51^{\mathrm{bc}}$ & $1.77^{\mathrm{b}}$ & $3.49^{\mathrm{a}}$ & 0.27 \\
\hline $\mathrm{C} 18: 2 \mathrm{c}-9, \mathrm{t}-11$ & $2.14^{\mathrm{a}}$ & $1.51^{\mathrm{b}}$ & $1.36^{\mathrm{bc}}$ & $1.27^{\mathrm{c}}$ & 0.11 \\
\hline SCFA & $6.38^{\mathrm{d}}$ & $17.80^{\mathrm{b}}$ & $11.53^{\mathrm{c}}$ & $21.68^{\mathrm{a}}$ & 1.77 \\
\hline MCFA & $28.39^{\mathrm{b}}$ & $39.34^{\mathrm{a}}$ & $37.78^{\mathrm{a}}$ & $40.65^{\mathrm{a}}$ & 1.50 \\
\hline LCFA & $65.23^{\mathrm{a}}$ & $42.85^{\mathrm{c}}$ & $50.69^{\mathrm{b}}$ & $37.67^{\mathrm{d}}$ & 3.16 \\
\hline PUFA & $6.84^{\mathrm{a}}$ & $4.60^{\mathrm{c}}$ & $6.04^{\mathrm{b}}$ & $6.67^{\mathrm{a}}$ & 0.27 \\
\hline VA/CLA ratio & $1.48^{\mathrm{c}}$ & $1.77^{\mathrm{b}}$ & $1.63^{\mathrm{bc}}$ & $2.17^{\mathrm{a}}$ & 0.08 \\
\hline$\Delta^{9}$-desaturase index & $0.020^{\mathrm{ab}}$ & $0.018^{b}$ & $0.022^{\mathrm{a}}$ & $0.014^{\mathrm{c}}$ & 0.001 \\
\hline Atherogenicity index & $0.83^{\mathrm{d}}$ & $2.19^{\mathrm{b}}$ & $1.62^{\mathrm{c}}$ & $2.72^{\mathrm{a}}$ & 0.21 \\
\hline
\end{tabular}

${ }^{\mathrm{a}, \mathrm{b}, \mathrm{c}, \mathrm{d}}$ Forage effect: means within row with different superscripts $\operatorname{differ}(P<0.05)$.

${ }^{1}$ Fatty acids: C4:0, butyric acid; $\mathrm{C} 6: 0$, caproic acid; C8:0, caprylic acid; $\mathrm{C} 10: 0$, capric acid; C12:0, lauric acid; C14:0, myristic acid; C14:1 cis-9, myristoleic acid; C15:0, pentadecanoic acid; C16:0, palmitic acid; C16:1 cis-9, palmitoleic acid; C17:0, margaric acid; C18:0, stearic acid; C18:1 trans-11, vaccenic acid; C18:1 cis-9, oleic acid; C18:2 n-6, linoleic acid; C18:3 n-3, linolenic acid; C18:2 c-9, t-11, rumenic acid; SCFA, shortchain fatty acids; MCFA, medium-chain fatty acids; LCFA, long-chain fatty acids; PUFA, polyunsaturated fatty acids; VA/CLA, vaccenic acid to rumenic acid ratio.

\section{CONCLUSIONS}

The feeding regimens based on the different forage species under study markedly affected (probably directly and indirectly, i.e., through fat mobilization) the fatty acid composition of Sarda sheep milk and cheese. During winter, with immature forages and early lactating sheep, Chrysanthemum coronarium and burr medic showed a clear advantage in terms of rumenic and vaccenic acid contents in milk fat. In spring, with reproductive forages and midlactating sheep, Chrysanthemum coronarium out-yielded the other treatments, which ranked as follows: $\mathrm{BM}>\mathrm{RY}>\mathrm{SU}$. The nonconventional daisy forage showed the best atherogenicity index in both experiments. Feeding Sulla resulted in a very high content of putatively beneficial linolenic acid but performed less well in terms of atherogenicity index. The fatty acid composition did not differ within feeding group between milk, 1-d-old cheeses, and 60-d-old cheeses, suggesting that the fatty acid recovery rates during cheese-making and ripening were not affected by the feeding regimens. Generally, the fatty acid profiles of the dairy products were well discriminated between dietary regimens. Based on these results, it can
Table 8. Stepwise discriminant analysis statistics and standardized canonical discriminant function coefficients.

\begin{tabular}{lcc}
\hline & \multicolumn{2}{c}{ Function } \\
\cline { 2 - 3 } & 1 & 2 \\
\hline Eigen value & 74.43 & 20.17 \\
Explained variance (\%) & 75.80 & 20.50 \\
Canonical correlation $_{\text {Wilks' } \Lambda^{1}}$ & 0.99 & 0.98 \\
Significance $^{2}$ & 0.000 & 0.010 \\
Fatty acids $^{3}$ & 0.000 & 0.000 \\
C14:0 & & \\
C15:0 & 4.225 & -0.357 \\
C16:1 cis-9 & -1.040 & 0.402 \\
C17:0 & -0.110 & 0.045 \\
C18:0 & -0.149 & 0.666 \\
C18:1 cis-9 & -0.232 & -0.639 \\
C18:2 n-6 & 3.132 & -1.266 \\
C18:2 n-3 & 0.360 & 0.411 \\
C18:2 c-9, t-11 & -1.808 & 0.516 \\
\hline
\end{tabular}

${ }^{1}$ Test of functions first column: 1 through 3 , second column: 2 through 3 .

${ }^{2}$ Significance of Wilks' $\Lambda$ determined from $\chi^{2}$ distribution.

${ }^{3}$ Fatty acids: C14:0, myristic acid; C15:0, pentadecanoic acid; C16:1 cis-9, palmitoleic acid; C17:0, margaric acid; C18:0, stearic acid; C18:1 cis-9, oleic acid; C18:2 n-6, linoleic acid; C18:3 n-3, linolenic acid; C18:2 c-9, t-11, rumenic acid. 


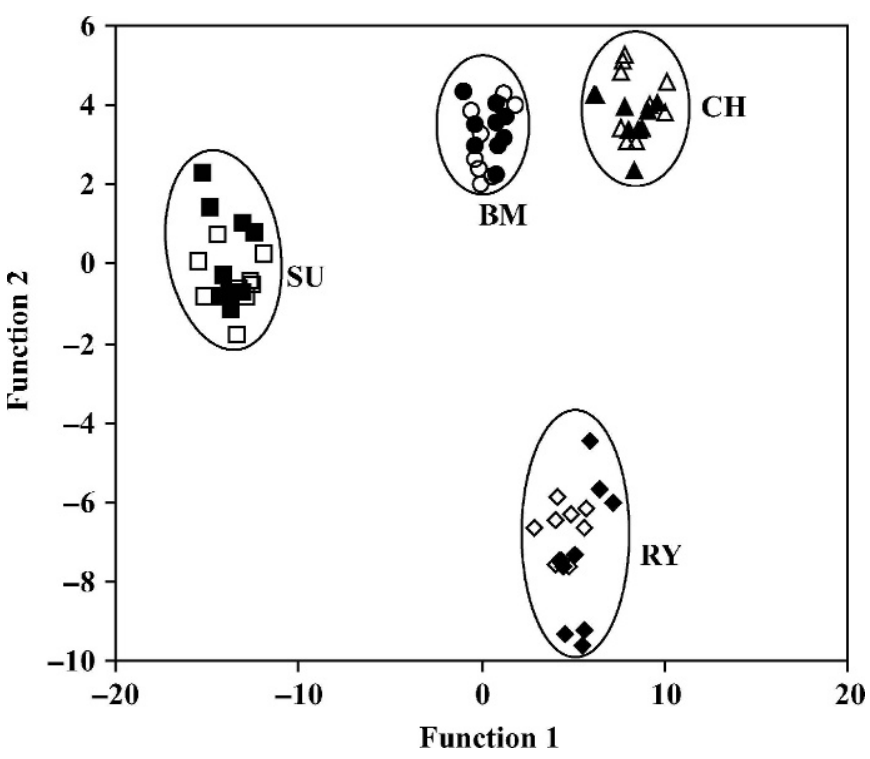

Figure 1. Distribution of milk, 1-d-old cheeses, and 60-d-old cheeses using the 2 canonical discriminant functions. ( $\square, \square)$ SU: sulla; $(\diamond, \diamond) \mathrm{RY}$ : annual ryegrass; $(\bullet, \bigcirc)$ BM: burr medic; $(\boldsymbol{\Delta}, \triangle)$ CH: Chrysanthemum coronarium. The solid symbols represent milk and cheeses from experiment 1 , the open symbols represent milk and cheeses from experiment 2 .

be concluded that the fatty acids profile of sheep dairy products can be manipulated to some extent with the aim of optimizing the content of beneficial fatty acids by adequate use of fresh forage-based diets without fatenriched supplementation.

\section{ACKNOWLEDGMENTS}

The authors gratefully acknowledge the skillful advice of Maria Sitzia for the establishment of forage plots, and recognize the technical assistance by Martina Krüger, Simona Spada, and Myriam Fiori, as well as the collaboration of all technical staff working at the laboratories of Istituto Zootecnico e Caseario per la Sardegna.

\section{REFERENCES}

Andrieu, J., C. Demarquilly, and D. Sauvant. 1988. Tables des valeur nutritive des aliments. Pages 351-443 in Aliments des Bovins, Ovins et Caprins. R. Jarrige, ed. INRA Pub., Paris, France.

AOAC. 1980. Official Methods of Analysis. 13th ed., Association of Official Analytical Chemists, Washington, DC.

Avondo, M., V. Fasone, I. R. Pagano, A. Crescione, and V. Galofaro. 2002. Effetto della percentuale di pascolo nella dieta sul contenuto di acido linoleico coniugato (CLA) nel latte ovino. Page 134 in Proc. Società Italiana di Patologia ed Allevamento degli Ovini e dei Caprini (S.I.P.A.O.C), Cagliari, Italy. (Abstr. in Italian). Kassiopea Group, Cagliari, Italy.

Banni, S., G. Carta, M. S. Contini, E. Angioni, M. Deiana, M. A. Dessì, M. P. Melis, and F. P. Corongiu. 1996. Characterization of conjugated diene fatty acids in milk, dairy products and lamb tissues. Nutr. Biochem. 7:150-155.
Bauchart, D., R. Verite, and B. Remond. 1984. Long-chain fatty acid digestion in lactating cows fed fresh grass from spring to autumn. Can. J. Anim. Sci. 64(Suppl.):330-331.

Bocquier, F., and G. Caja. 2001. Production et composition du lait de brebis: Effets de l'alimentation. INRA Prod. Anim. 14:129-140.

Cabiddu, A., G. Carta, G. Molle, M. Decandia, M. Addis, G. Piredda, A. Delogu, A. Pirisi, V. Lai, V. Cera, L. Taras, C. Lallai, and S. Banni. 2003. Relationship between feeding regimen and content of conjugated linoleic acid in sheep milk and cheese. Proc. 1st Joint Seminar of the FAO-CIHEAM Sheep and Goat Nutrition and Mountain and Mediterranean Pastures sub-Networks. Options Meditérranéennes (accepted).

Chilliard, Y., A. Ferlay, and M. Doreau. 2001. Effect of different types of forages, animal fat or marine oils in cow's diet on milk fat secretion and composition, especially conjugated linoleic acid (CLA) and polyunsaturated fatty acids. Livest. Prod. Sci. 70:31-48.

Chilliard, Y., A. Ferlay, R. M. Mansbridge, and M. Doreau. 2000. Ruminant milk fat plasticity: Nutritional control of saturated, polyunsaturated, trans and conjugated fatty acids. Ann. Zootec. 49:181-205.

Chilliard, Y., A. Ferlay, J. Rouel, and G. Lamberet. 2003. A review of nutritional and physiological factors affecting goat milk synthesis and lipolysis. J. Dairy Sci. 86:1751-1770.

Chin, S. F., W. Liu, J. M. Storkson, Y. L. Ha, and M. W. Pariza. 1992. Dietary sources of conjugated dienoic isomers of linoleic acid, a newly recognized class of anticarcinogens. J. Food Comp. Anal. 5:185-197.

Christie, W. W. 1989. Gas Chromatography and Lipids: A practical guide, 1st ed. The Oily Press, Dundee, UK.

Collomb, M., U. Butikofer, R. Sieber, B. Jeangros, and J. O. Bosset. 2002. Composition of fatty acids in cow's milk fat produced in the lowlands, mountains and highlands of Switzerland using highresolution gas chromatography. Int. Dairy J. 12:649-659.

Decaen, C., and M. B. Ghadaki. 1970. Influence de la mise à l'herbe, de la nature de l'herbe et de son stade de vegetation sur la sécrétion des acides gras des matières grasses du lait. Ann. Zootec. 19:399-411.

Delegarde, R., and J. L. Peyraud. 2002. Fatty acid composition of milk from dairy cows as affected by grazing different grass species or cultivars. Pages 554-555 in Multi-Function Grasslands, Quality, Forages, Animal Products and Landscapes, Grassland Science in Europe. Vol. 7. J. L Durand, J. C. Emile, C. Huyghe, and G. Lemaire, ed. Association Francaise pour la Production Fourragère, Versailles, France.

Dewhurst, R. J., N. D. Scollan, S. J. Youell, K. K. S. Tweed, and M. O. Humphreys. 2001. Influence of species, cutting date and cutting interval on the fatty acid composition of grasses. Grass Forage Sci. 56:68-74.

Dhiman, T. R., G. R. Anand, L. D. Satter, and M. W. Pariza. 1999. Conjugated linoleic acid content of milk cows fed different diets. J. Dairy Sci. 82:2146-2156.

Elgersma, A., G. Ellen, H. van de Horst, B. G. Muuse, H. Boer, and S. Tamminga. 2003. Influence of cultivar and cutting date on the fatty acid composition of perennial ryegrass (Lolium perenne L.). Grass Forage Sci. 58:323-331.

French, P., C. Stanton, F. Lawless, E. G. O’Riordan, F. J. Monahan, P. J. Caffrey, and A. P. Moloney. 2000. Fatty acid composition, including conjugated linoleic acid, of intramuscular fat from steers offered grazed grass, grass silage or concentrate-based diets. J. Anim. Sci. 78:2849-2855.

Griinari, J. M., and D. E. Bauman. 1999. Biosynthesis of conjugated linoleic acid and its incorporation into meat and milk in ruminants. Pages 180-200 in Advances in Conjugated Linoleic Acid Research. Vol. 1. M. P. Yurawecz, M. M. Mossoba, J. K. G. Kramer, M. W. Pariza, and G. J. Nelson, ed. AOCS Press, Champaign, IL.

Holmes, C. W. 1974. The Massey grass meter. Pages 26-30 in Dairy Farming Annual. Massey Univ., Palmerston North, New Zealand.

Hume, D. E., T. B. Lyons, and R. J. M. Hay. 1995. Evaluation of grasslands Puna chicory (Cichorium intibus L.) in various grass mixtures under sheep grazing. N.Z. J. Agric. Res. 38:317-328. 
Ip, C., Y. Dong, M. M. Ip, S. Banni, G. Carta, E. Angioni, E. Murru, S. Spada, M. P. Melis, and A. Sæbø. 2002. Conjugated linoleic acid and mammary cancer prevention. Nutr. Cancer 43:52-58.

Jensen, R. G. 2002. The composition of bovine milk lipids: January 1995 to December 2000. J. Dairy Sci. 85:295-350.

Kuzdal-Savoie, S., and W. Kuzdal. 1961. Influence de la mise à l'herbe des vaches laitères sur les indices de la matière grasse du beurre et sur les teneurs en différents acides gras polyinsaturés. Ann. Biol. Anim. Biochem. Biophys. 1:47-69.

Landau, S., S. Friedman, S. Brenner, I. Bruckental, Z. G. Weinberg, G. Ashbell, Y. Hen, L. Dvash, and Y. Leshem. 2004. The value of safflower (Carthamus tinctorius) hay and silage grown under Mediterranean conditions as forage for dairy cattle. Livest. Prod. Sci. 88:263-271.

Lock, A. L., and P. C. Garnsworthy. 2003. Seasonal variation in milk conjugated linoleic acid and $\Delta^{9}$-desaturase activity in dairy cows. Livest. Prod. Sci. 79:47-59.

Makkar, H. P. S. 2001. Chemical protein precipitation and bioassays for tannins, effects and fate of tannins and strategies to overcome detrimental effects of feeding tannins-rich feeds. Pages 40-41 in Proc. IX FAO-CIHEAM Meeting on Sheep and Goat Nutrition, Hammamet, Tunisia.

Molle, G., M. Decandia, N. Fois, S. Ligios, A. Cabiddu, and M. Sitizia. 2003. The performance of Mediterranean dairy sheep given access to sulla (Hedysarum coronarium L.) and annual ryegrass (Lolium rigidum Gaudin) pastures in different time proportions. Small Rumin. Res. 49:319-328.

Molle, G., M. Decandia, S. Ligios, N. Fois, and M. Sitzia. 2002. Grazing management and stocking rate with particular reference to Mediterranean environments. Pages 285-313 in Dairy sheep feeding and nutrition. G. Pulina, ed. Avenue Media, Bologna, Italy.

Nudda, A., M. A. McGuire, G. Battacone, and G. Pulina. 2005. Seasonal variation in conjugated linoleic acid and vaccenic acid in milk fat of sheep and its transfer to cheese and ricotta. J. Dairy Sci. 88:1311-1319.

Offer, N. W. 2002. Effect of cutting and ensiling grass on levels of CLA in bovine milk. Proceedings of International Silage Conference, Auchincruive, UK. L. M. Gechie and C. Thomas, ed. SAC, Auchincruive, UK.

Parodi, P. W. 2003. Anti-cancer agents in milk fat. Aust. J. Dairy Technol. 58:114-118.

Perea, S., E. F. de Labastida, A. I. Nàjera, F. Chàvarri, M. Virto, M. de Renobales, and L. J. R. Barron. 2000. Seasonal changes in the fat composition of Lacha sheep's milk used for Idiazabal cheese manufacture. Eur. Food Res. Technol. 210:318-323.

Piredda, G., S. Banni, G. Carta, A. Pirisi, M. Addis, and G. Molle. 2002. Influenza dell'alimentazione al pascolo sui livelli di acido rumenico in latte e formaggio ovino. Progr. Nutr. 4:1-5. (Abstr. in English)

Reed, J. D., C. Krueger, G. Rodriguez, and J. Hanson. 2000. Secondary plant compounds and forage evaluation. Pages 433-448 in Forage Evaluation in Ruminant Nutrition. D. I. Given, ed. CABI Publishing, Wallingford, UK.

Rochon, J. J., C. J. Doyle, J. M. Greef, A. Hopkins, G. Molle, M. Sitzia, D. Scholefield, and C. J. Smith. 2004. Grazing legumes in Europe: A review of their status, management, benefits, research needs and future prospects. Grass Forage Sci. 59:197-214.

Russel, A. J. F., J. M. Doney, and R. G. Gunn. 1969. Subjective assessment of body fat in live sheep. J. Agric. Sci. 72:451-454.

Sessler, A. M., and J. M. Ntambi. 1998. Polyunsatured fatty acid regulation of gene expression. J. Nutr. 128:923-926.

Sulas, L., G. A. Re, G. Molle, and S. Ligios. 1999. Chrysanthemum coronarium L.: A new pasture species for Mediterranean forage system. Cahiers Options Méditerranées. 39:83-86.

Williams, C. M. 2000. Dietary fatty acids and human health. Ann. Zootec. 49:165-180. 